\title{
Role of glass eel salinity preference in the control of habitat selection and growth plasticity in Anguilla anguilla
}

\author{
Eric Edeline ${ }^{1, *}$, Sylvie Dufour ${ }^{2}$, Pierre Elie $^{1}$ \\ ${ }^{1}$ Cemagref, Unité ‘Ecosystèmes Estuariens et Poissons Migrateurs Amphihalins' (EPBX), 50 Avenue de Verdun, \\ 33612 Cestas Cedex, France \\ ${ }^{2}$ Muséum National d'Histoire Naturelle, USM 0401, UMR CNRS/MNHN/UPMC 5178 `Biologie des Organismes Marins \\ et Ecosystèmes', Bâtiment de Physiologie, 7 rue Cuvier, 75231 Paris Cedex 05, France
}

\begin{abstract}
Eels colonize either marine, estuarine or freshwater habitats, with marine and estuarine eels tending to grow faster than freshwater eels. The reasons for these divergent migratory tactics and growth trajectories remain poorly understood. In order to investigate the role of salinity preferences of glass eels in the control of habitat selection and growth plasticity, we sorted different contingents of glass eels Anguilla anguilla through 2 consecutive salinity preference tests. This allowed us to study the link between salinity preference and locomotor activity (i.e. positive rheotaxis), and to distinguish contingents of glass eels that were either plastic or fixed in their preference for freshwater (FW) or saltwater (SW). Subsequently, we monitored somatic growth of the different contingents in controlled SW and FW rearing conditions. Preference for FW was linked to high locomotor activity, a behavioral pattern likely to promote colonization of FW habitats in the wild. Accordingly, FWC (FW contingent, i.e. glass eels that preferred FW twice) exhibited poor growth, similar to those observed in wild FW eel populations. In contrast, preference for SW was linked to low locomotor activity, and the SWC (SW contingent, i.e. glass eels that preferred SW twice) had high growth rates in SW, as observed in wild marine and estuarine populations. The PCC (plastic contingent, i.e. glass eels that swappped their salinity preference) had an intermediary growth status that could be related to the 'nomad' life style of eels migrating between different habitat types during their life. Growth was significantly higher in SW compared to FW in all contingents, indicating that habitat salinity may directly affect growth, irrespective of food availability. Our results demonstrated that glass eel salinity preference was linked to their locomotor activity and growth performance, and provided a comprehensive ecological mechanism for the control of habitat distribution and growth patterns observed in wild eel populations.
\end{abstract}

KEY WORDS: Glass eel · Anguilla anguilla $\cdot$ Divergent migratory tactics $\cdot$ Habitat selection $\cdot$ Life history plasticity $\cdot$ Salinity preference $\cdot$ Locomotor activity $\cdot$ Growth

Resale or republication not permitted without written consent of the publisher

\section{INTRODUCTION}

Worldwide, freshwater eel stocks are currently collapsing (Stone 2003). In this context, a better understanding of the proximate drivers of eel distribution in marine, estuarine and freshwater habitats would be invaluable for the improvement of management policies.
At the end of their transoceanic migration, leptocephalus larvae metamorphose into glass eels that subsequently invade coastal and inland habitats using selective tidal stream transport (STST) (McCleave \& Kleckner 1982, Gascuel 1986, McCleave \& Wippelhauser 1987). They ascend from the bottom and are carried by tidal currents during the flood tide. During slack water, they return to the bottom, where they 
remain during the ebb tide. Migration is therefore achieved through saltatory steps. Vertical movements in the water column are cued by an internal circatidal clock, the rhythm of which is controlled by flow reversals (Wippelhauser \& McCleave 1988). During STST, glass eels also orientate towards the mouth of rivers and up-estuary following olfactory cues from river waters (Sorensen 1986, Tosi \& Sola 1993, Sola 1995). Larval feeding activity stops at the onset of metamorphosis (Schmidt 1909), and is resumed and conditioned at the glass eel stage by the acquisition of a new set of teeth and physiological development of the gut (Elie 1979, Tesch 2003).

Microchemical otolith studies have shown that glass eels may either colonize freshwater (FW) habitats or stop their migration and settle in saltwater (SW) as soon as they reach coastal and estuarine habitats (Tzeng et al. 1997, 2002, Tsukamoto \& Arai 2001, Jessop et al. 2004). Moreover, some 'nomad' individuals migrate between SW and FW habitats throughout their life (Feunteun et al. 2003, Daverat et al. 2004). The reasons for these divergent migratory tactics are still only partially understood. Furthermore, marine and estuarine eels grow faster than river eels (Fernandez-Delgado et al. 1989, Mounaix \& Fontenelle 1994, Tzeng et al. 2003, Arai et al. 2004, Jessop et al. 2004). The reasons for these growth discrepancies remain obscure.

Salinity is a major environmental factor that may shape fish community structures (Davenport \& Sayer 1993, Jung \& Houde 2003) and affect growth in numerous teleost fish species (Boeuf \& Payan 2001). In the flathead mullet Mugil cephalus, field and laboratory studies showed that variations of salinity tolerance during development could control habitat selection (Cardona 2000). The behavior of glass eels in response to salinity is far from understood. Glass eels always survive acute salinity challenges during abrupt transfer between FW and SW (Fontaine \& Raffy 1932, Wilson et al. 2004), but glass eels arriving from the sea seem to need a delay period before showing voluntary entry into FW (Petit \& Vilter 1944, Deelder 1958, Sorensen \& Bianchini 1986). This suggests that glass eels may exhibit salinity tolerance variations in terms of osmoregulatory ability. Accordingly, experimental behavioral studies indicate that, although the majority of Anguilla anguilla glass eels are FW-seeking, the proportion of SW-seeking fish may still reach 30 to $50 \%$ (Tosi et al. 1988, 1989, 1990). Moreover, some individuals may reverse their salinity preference from FW towards SW over an acclimatization period in brackish water (E. Edeline et al. unpubl. data). These salinity preference patterns fit with the different salinity histories (marine, estuarine, riverine and nomad) observed in yellow and silver eels during microchemical otolith studies (Tsukamoto \& Arai 2001, Daverat et al. 2004, Jessop et al. 2004), suggesting that interindividual variations in glass eel salinity preference could be involved in habitat selection and utilization.

In order to investigate how glass eel salinity preference may be involved in the control of the eel life history plasticity, we sorted different contingents of glass eels through 2 consecutive salinity preference tests. This allowed us to study the link between salinity preference and locomotor activity, and to separate contingents of glass eels that were either plastic or fixed in their preference for FW or SW. Subsequently, we monitored growth of the different glass eel contingents in controlled SW and FW rearing conditions. The links between salinity preference, locomotor activity and growth provided new insights into the ecological and physiological mechanisms involved in the control of the eel continental distribution and growth patterns.

\section{MATERIALS AND METHODS}

Fish collection. Glass eels were netted at the mouth of the Gironde estuary during the night of 26 March 2002 (flood tide, $18 \%$ and $10^{\circ} \mathrm{C}$ water) at Le Verdon, France. As the eels were caught just after their arrival from the sea, they were considered to be homogenous in terms of salinity history. At this particular geographic location, glass eels are at an early stage of metamorphosis, i.e. they have not yet restarted feeding and growth (Cantrelle 1981, Elie et al. 1982). The glass eels were immediately transferred to the Cemagref's biological station of Saint Seurin sur Isle in aerated natural estuarine water, and then kept unfed for 1 to $3 \mathrm{~d}$ in $18 \%$ synthetic sea salt (Instant Ocean) and $18^{\circ} \mathrm{C}$ drill hole water, under a natural photoperiod.

Behavioral test apparatus. The behavioral test apparatus was similar to that of Tosi et al. (1988), modified to include 3 tanks providing a triplicate for each experiment (Fig. 1). This experimental apparatus allowed us to assess concurrently both salinity preference and locomotor activity (i.e. positive rheotaxis) of glass eels, a behavioral trait strongly related to the propensity to colonize inland habitats in the eel (Castonguay et al. 1990, Edeline et al. 2004, 2005).

Each tank was divided into 2 compartments by a wall into which the mouths of 2 traps opened delivering flows of drill hole water, either fresh $(0 \%)$ or salted (33\%, synthetic sea salt), which presented a binary choice for glass eels. The choice compartment (A) in Fig. 1, receiving glass eels, was filled with $15 \mathrm{l}$ of $17^{\circ} \mathrm{C}$, $18 \%$ drill hole water (synthetic sea salt). Each trap (B) in Fig. 1 consisted of a plastic funnel inserted through 


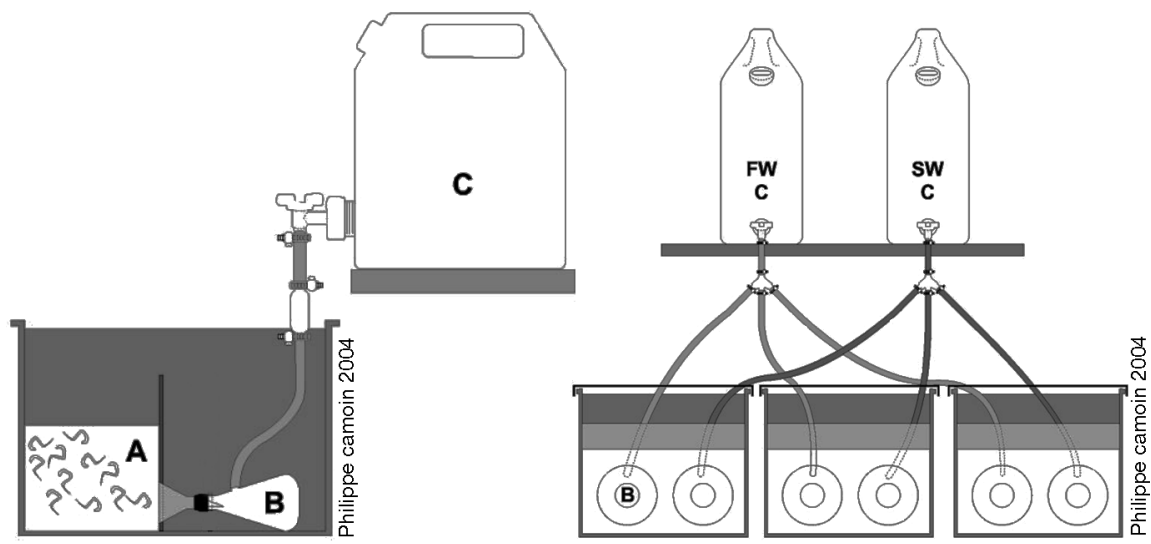

Fig. 1. Experimental device used to test salinity preference of glass eels. A: choice compartment, B: trap compartment, C: water header reservoir, FW: freshwater $(0 \%)$, SW: saltwater $(33 \%)$

a cork into the neck of a flask, through which water flowed. Water was gravity-delivered from 101 water reservoirs (C) in Fig. 1 to each tank, flowing through taps limiting the flow to $0.141 \mathrm{~min}^{-1}$. In order to avoid any light effect on eel choice, tanks were covered with lids. Glass eels were therefore kept in the dark throughout the trials.

In order to decrease stress, glass eels were kept for 10 min in the dark before starting the trials. Constant temperatures were maintained $\left(17^{\circ} \mathrm{C}\right)$ between flowing and acclimatization waters. Glass eels were counted volumetrically, and 100 glass eels per tank were tested during 20 min trials $(\sim 3 \times 100$ glass eels per trial, 11 trials). Glass eels were subsequently counted individually at the end of each trial. Glass eels caught in the traps had actively swum towards a water flow, and were considered as active, i.e. to have exhibited a locomotor activity. They were considered to have preferred FW or SW, respectively, depending on whether they were in the traps connected to the FW or SW reservoir. In contrast, glass eels that remained in the choice compartment (A) had not responded to the water flow and were considered as inactive (i.e. sedentary). In this protocol, sedentary behavior may reflect both low locomotor activity and preference for brackish water.

Behavioral testing of glass eels. We developed 2 consecutive behavioral tests (over a 10 d acclimatisation period) in order to (1) assess the sustainability of the behavioral responses over 2 consecutive tests, (2) study the behavioral link between locomotor activity and salinity preference, and (3) discriminate salinity preference in contingents of glass eels for the growth experiment.

During the first trial series, 3193 glass eels were tested for salinity preference 1, 2 and $3 \mathrm{~d}$ after capture; 864 were active (i.e. actively swam towards either a FW or a SW flow). All the active glass eels, as well as a batch $(\mathrm{n}=543)$ of inactive fishes, were kept in $18^{\circ} \mathrm{C}, 18 \%$ water to perform the second behavioral test. The other fishes (the rest of the inactive glass eels) were released.

During the second trial series, we tested these 2 batches (543 inactive and 864 active glass eels) for their salinity preference, 9 and $10 \mathrm{~d}$ after capture. After the second trial, the 543 glass eels that had been inactive during the first trial were released. Among the 864 glass eels that had been active during the first trial series, 526 were again active during the second trial series. These 526 fishes were used to carry out the growth experiment, while the others were released.

We classified the 526 glass eels that were active during the 2 trials into contingents according to their salinity preference: FWC $(\mathrm{n}=240)$ for FW contingent (double preference for FW), SWC ( $\mathrm{n}=47$ ) for SW contingent (double preference for SW), and PCC ( $\mathrm{n}=239)$ for plastic contingent (shift in salinity preference over the acclimatization period: from SW to FW, or from FW to SW). Glass eels from these 3 contingents were then reacclimatized for 4 to $6 \mathrm{~d}$ in $18 \%$, $18^{\circ} \mathrm{C}$, drill hole water under natural light:dark conditions before starting the growth experiment.

Growth experiment. Each contingent was divided in two, half the eels for rearing in FW $(0 \%$ o drill hole water) and half the eels for rearing in SW (34\%o drill hole water, synthetic sea salt), using a natural photoperiod and a water temperature of $18^{\circ} \mathrm{C}$. Glass eels were fed in excess with identical rations of eel fry food (Biomar).

Eight glass aquaria (35 l) were used, each divided in 3 compartments by 3 circular plastic fences with a density of 20 to 24 ind. per compartment. In order to avoid a possible 'aquarium effect' on growth, the compartments used for rearing of each contingent were distributed among different aquaria. Each aquarium was equipped with a recirculation system. Water treatment was provided by a $25 \mathrm{~W}$ UV lamp and a sponge filter supplied by a small pump fixed on the bottom of the aquarium. Three tubes were inserted at the base of the sponge filter bowl and reinjected water into the 
aquarium through the top of each fence. Moreover, a small sponge and charcoal filter completed the water treatment and provided a slight water current. Food waste and faeces were regularly siphoned out of the aquaria.

Measurements. The beginning of the growth experiment was termed Day 1. Individual measurements were made at Days 1, 15, 32, 47 and 66. Glass eels were anesthetized with clove oil $(10 \%$ diluted in ethanol, $4 \mathrm{ml} \mathrm{l}^{-1}$ ) and individually measured for body length (BL) to the nearest $\mathrm{mm}$. After they had recovered, eels were put back into their aquarium compartment. This procedure reduced the handling mortality to 0 . In order to limit additional handling stress that may impair growth (Wickins 1987), glass eels were not weighed during the growth period. However, in order to evaluate productivity, after drying on blotting paper, eels were individually weighed to the nearest $0.01 \mathrm{~g}$ at the end of the growth experiment (Day 66).

Data analysis. Statistical analysis was carried out using Systat 11 (SPSS). Results are given as mean \pm SD.

Behavioral experiment: We used a 1-way Pearson's $\chi^{2}$ test for analysis of differences in salinity preferences and locomotor activity during the first trial series. Moreover, we tested how locomotor activity during the first trial (Locomotor activity1, i.e. the probability to swim upstream irrespective of salinity preference) affected locomotor activity and salinity preference during the second trial with a binomial logistic regression model (logit) of the following form:

$$
\ln [p /(1-p)]=\alpha+\beta_{1}(\text { Locomotor activity } 1)+\varepsilon
$$

where $p$ is either the probability for being active or the probability for preferring FW to SW when active, $\alpha$ is a constant, $\beta_{1}$ is the coefficient of the independent variable 'Locomotor activity1', and $\varepsilon$ is random error. The effect of the tank was not statistically significant and 'Tank' effect was therefore not included in the model.

Growth experiment: For analysis of growth, BL were log-linearized to fit distributions to normality (Kolmogorov-Smirnov test, $\mathrm{p}<0.0005)$. Then, after checking for homogeneity of variances (Bartlett's test, p < 0.0005), the effects of the 'Rearing salinity' and 'Contingent' variables on BL were tested using an ANCOVA with 'Time' as a covariate. Pairwise comparisons were made using Bonferroni multiple comparison test.

Survival rates: We calculated survival rates from the counts of eels at each measurement at Days 1, 15, 32, 47 and 66. Due to the low number of reference points, we analyzed the effects of the 'Contingents' and 'Rearing salinity' variables on cumulated mortality percentages using a non-parametric test Kruskal-Wallis test (KW) and a Mann-Whitney $U$-test, respectively.

\section{RESULTS}

\section{Behavioral experiment}

During the first behavioral trial series $(\mathrm{n}=3193$ glass eels, 11 trials), $18 \pm 12 \%$ of the glass eels actively swam towards FW, $9 \pm 7 \%$ towards SW, and $73 \pm 14 \%$ were inactive. Inactive glass eels were significantly more numerous than active eels (1-way Pearson's $\chi^{2}, \mathrm{df}=1$, $\mathrm{p}<0.0005)$. Among active glass eels, $65 \pm 21 \%$ preferred FW to SW, a highly significant difference (1-way Pearson's $\chi^{2}$, df $\left.=1, \mathrm{p}<0.0005\right)$.

In the second behavioral trial series, glass eels that had been active during the first trial were significantly more active than glass eels that had been inactive during the first trial (logit, df $=1, \mathrm{p}<0.0005$ ). This result indicates that glass eels tended to maintain their locomotor activity level over the acclimatization period.

Glass eels that preferred FW during the first trial significantly preferred FW to SW when active during the second trial ( $\mathrm{n}=6$ tanks, 583 glass eels; FW: $45 \pm 14 \%$; SW: $22 \pm 16 \%$; inactive: $33 \pm 10 \%$ ). Interestingly, glass eels that had preferred SW during the first trial also significantly preferred FW to SW when active during the second trial ( $\mathrm{n}=3$ tanks, 281 glass eels; FW: $46 \pm$ $15 \%$; SW: $21 \pm 15 \%$; inactive: $33 \pm 10 \%$ ). This result indicates that a sustained high locomotor activity over the 2 behavioral tests was linked to a higher preference for FW than for SW. In contrast, glass eels that had been inactive during the first trial significantly preferred SW to FW when active during the second trial ( $\mathrm{n}=6$ tanks, 542 glass eels; FW: $10 \pm 5 \%$; SW: $16 \pm$ $7 \%$; inactive: $74 \pm 6 \%$ ), indicating that a low locomotor activity was linked to a higher preference for SW than for FW. When tested with the logistic regression model, this link between locomotor activity and salinity preference was highly significant (logit, $\mathrm{df}=1, \mathrm{p}<0.0005$ ).

\section{Growth experiment}

Effects of the 'Time', 'Rearing salinity' and
'Contingent' variables on growth

The average BL of glass eels on Day 1 was $75.2 \pm$ $4.3 \mathrm{~mm}(\mathrm{n}=526)$. At the end of the experiment, this value was $75.5 \pm 9.8 \mathrm{~mm}$ in $\mathrm{FW}(\mathrm{n}=197)$, and $86.2 \pm$ $14.7 \mathrm{~mm}$ in SW $(\mathrm{n}=108)$. The 'Time variable' significantly affected BL (ANCOVA, df =1, p < 0.0005), indicating that, irrespective of rearing salinity and contingents, BL significantly changed during the experiment (Fig. 2). Irrespective of contingents, growth of juvenile eels was significantly higher in SW than in FW (ANCOVA, df $=1, p<0.0005)$. This result was confirmed by the productivity data showing that the final total 


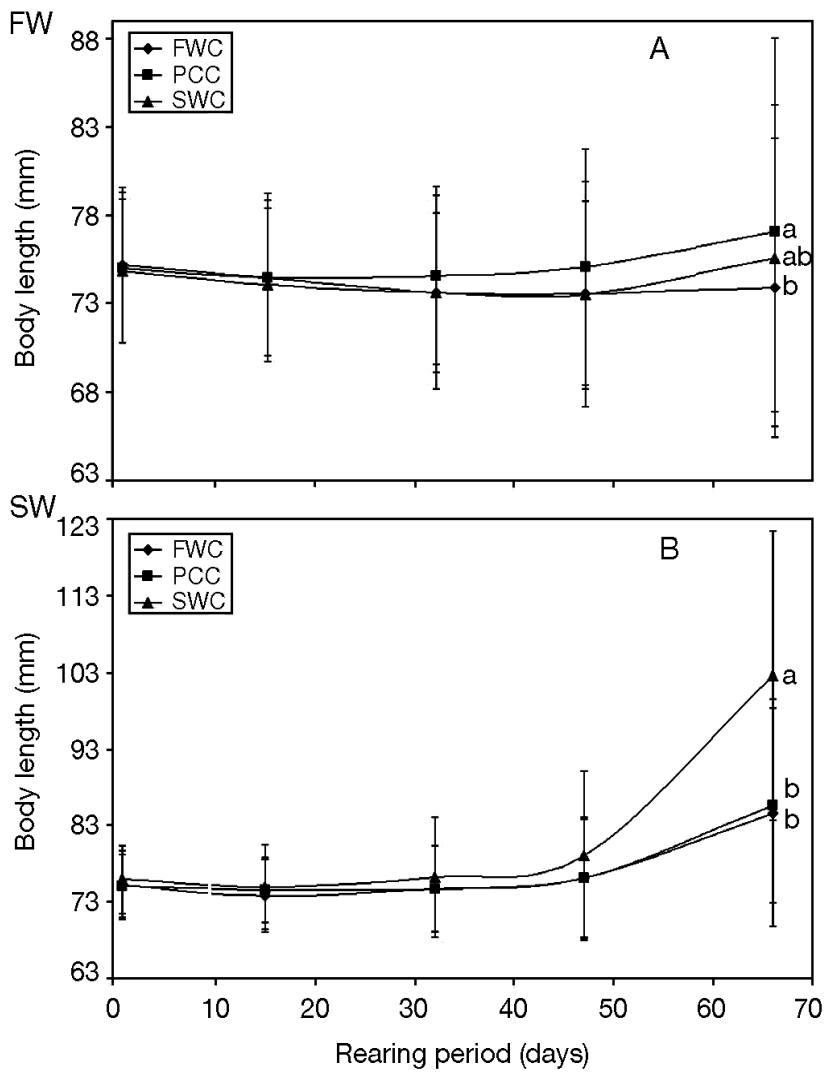

Fig. 2. Anguilla anguilla. Body length (mean $\pm \mathrm{SD}$ ) of 3 contingents of juvenile eels reared in (A) FW (freshwater) and (B) SW (seawater). FWC: FW contingent; SWC: SW contingent; PCC: plastic contingent. Lowercase letters indicate significant differences between contingents over the whole rearing period

biomass was $75.39 \mathrm{~g}$ in SW and $57.30 \mathrm{~g}$ in FW. Accordingly, we observed a more intense feeding activity and much less food left over in SW compared to FW.

Regardless of the rearing salinity, growth was significantly influenced by the 'Contingent' variable (ANCOVA, df $=2, p=0.018$ ). Indeed, irrespective of the rearing salinity, growth of FWC eels was significantly lower than that of PCC (Bonferroni, $p=0.031$ ) and SWC eels (Bonferroni, $p=0.017$ ). No other combination of contingent was significantly different for growth.

\section{Effects of the 'Time' and 'Contingent' variables on growth in FW versus SW}

In FW, BL was not significantly influenced by the 'Time' variable, indicating that growth was not significant over the experimental period (ANCOVA, df = $1, \mathrm{p}=0.606)$. Nevertheless, in FW, the 'Contingent' variable significantly affected BL (ANCOVA, df $=2$, $\mathrm{p}=0.019$ ) (Fig. 2A). Indeed, PCC eels grew significantly more than FWC eels (Bonferroni, $p=0.006$ ).
No other combination of contingents was significantly different for growth in FW.

In SW, BL was significantly affected by the 'Time' variable (ANCOVA, df $=1, \mathrm{p}<0.0005$ ), indicating that body growth was significant during the experimental period. Moreover, the 'Contingent' variable also significantly affected BL (ANCOVA, df $=2, p=0.015$ ) (Fig. 2B). Growth of the SWC eels was significantly higher than that of PCC (Bonferroni, p = 0.012) and FWC eels (Bonferroni, $p=0.004$ ). No other combination of contingents was significantly different for growth in SW.

\section{Survival rates}

An increase in mortality was monitored between Day 47 (6\% mortality) and Day 66 (35\% mortality). We observed that this effect was mainly due to cannibalism that started after Day 47, and seemed to occur more frequently in SW than in FW. However, survival rates were not significantly different between contingents (KW, df $=2, p=0.715$ ) and salinities (MannWhitney $U$-test, $\mathrm{df}=1, \mathrm{p}=0.848$ ).

\section{DISCUSSION}

It has recently been demonstrated in microchemical otolith studies that eels exhibit a flexible pattern of continental habitat colonization, either migrating upriver, or settling in marine and estuarine habitats (Tzeng et al. 1997, 2002, Tsukamoto \& Arai 2001, Daverat et al. 2004, Jessop et al. 2004). Furthermore, marine and estuarine eels tend to grow faster than river eels (Fernandez-Delgado et al. 1989, Mounaix \& Fontenelle 1994, Tzeng et al. 2003, Arai et al. 2004, Jessop et al. 2004). The drivers of these divergent life histories are still poorly understood. In the present study, we investigated the role of glass eel salinity preference in the control of the eel life history plasticity, by evaluating the link between salinity preference, locomotor activity and body growth.

\section{Link between salinity preference and locomotor activity}

Our first salinity preference test showed that, on arrival from the sea, most active glass eels preferred FW to SW, in accordance with the previous results of Tosi et al. (1988, 1989, 1990). However, through the second salinity preference test, we further demonstrated that a highly significant link exists between salinity preference and locomotor activity. Glass eels 
showing a high, sustained locomotor activity (swimming upstream during the 2 consecutive tests) significantly preferred FW to SW, whereas glass eels showing a low locomotor activity (inactive during 1 of the 2 tests) significantly preferred SW to FW when active. In the wild, locomotor activity is a behavioral trait strongly related to the migratory propensity, in both glass eels (Edeline et al. 2004, 2005) and yellow eels (Castonguay et al. 1990). Preference for FW in highly active glass eels is a behavioral pattern likely to promote the colonization of FW habitats, including lowdensity and lake habitats that support production of large female eels (Krueger \& Oliveira 1999, Oliveira et al. 2001). In contrast, low locomotor activity coupled to preference for SW is likely to promote precocious settlement in marine or estuarine habitats. Hence, our results support the view that salinity preference is connected to locomotor activity during the behavioral control of the distribution in habitats.

At the watershed scale, estuarine eels seem to be the most prevalent, ranging between 64 and $81 \%$ of the population (Tsukamoto \& Arai 2001, Tzeng et al. 2002, Jessop et al. 2004). This proportion is comparable to that of inactive glass eels during our first behavioral trial series (73\%), which exhibited no locomotor activity and remained in the brackish water of choice compartments. This result adds further support to the view that both locomotor activity and salinity preference may interact in driving the distribution in continental habitats. These sedentary brackish water glass eels, together with those recurrently choosing SW, were likely to represent the marine/estuarine ecotype.

The endocrine control of locomotor activity and salinity preference is likely to be regulated by a complex action of several mediators. In glass eels, increased thyroid hormone (TH) levels enhance locomotor activity and migratory behavior (Edeline et al. 2004, 2005) and, in other teleosts, TH have been shown to also affect salinity preference according to species and/or life stage (Baggerman 1960, 1962, Iwata 1995). Hence, TH could be involved in the regulation of the observed link between preference for FW and locomotor activity in glass eels. However, PCC glass eels changed their salinity preference while maintaining their locomotor activity, and a minority of active eels kept exhibiting a preference for SW. This indicates that the triggering mechanisms of locomotor activity and salinity preference may also be separated. This differential regulation could involve (in addition to $\mathrm{TH}$ ) growth hormone (GH) and cortisol, which both affect locomotor activity in teleosts (Overli et al. 2002, Johansson et al. 2004) and have a synergistic action for acclimation to SW (McCormick 2001).

\section{Link between habitat salinity and growth}

During the present experiments performed under controlled conditions, glass eel growth was significantly higher in SW compared to FW conditions, irrespective of previous salinity preference. This indicates that environmental salinity may directly affect juvenile eel growth. This result is in accordance with preliminary data from extensive eel pond culture, showing that glass eels and elvers grow faster in SW than in FW (P. Elie unpubl. data). Growth rate is a life history trait of major importance, which was suggested to influence sexual differentiation, and also age and size at silvering in both sexes (Vøllestad 1992, Holmgren \& Mosegaard 1996). Our data suggest that habitat salinity, through its effects on growth rates, may influence both population structure and dynamics.

In FW, growth curves showed that lengths started to increase again after $47 \mathrm{~d}$. Similar observations of arrested or negative growth rates at the start of glass eel rearing experiments have been reported previously (Bertin 1951, Elie \& Daguzan 1976, Elie 1979, De Silva et al. 2001). Indeed, the cessation of feeding and intense catabolism of energy stores associated with metamorphosis induces length and weight reduction (Schmidt 1909, Tesch 2003). When reared at temperatures above $20^{\circ} \mathrm{C}$ in $\mathrm{FW}$ with various diets, the delay before glass eels restart growing ranged from $28 \mathrm{~d}$ in Anguilla australis (De Silva et al. 2001) to $50 \mathrm{~d}$ in A. anguilla and A. rostrata (Appelbaum et al. 1998). Consequently, growth rates observed in $\mathrm{FW}$ at $18^{\circ} \mathrm{C}$ in the present study are within the range of standard growth rates for glass eels in captivity. At the end of the growth experiment (Day 66), glass eels reared in FW had recovered their initial BL. In contrast, glass eels reared in SW recommenced growth earlier (after $15 \mathrm{~d}$ ) and reached significantly longer BL at the end of the experiment.

In teleosts, salinity may affect growth through various mechanisms such as the standard metabolic rate, food intake and conversion, and hormonal stimulation (Boeuf \& Payan 2001). In glass eels, the early work of Fontaine \& Raffy (1932) showed that oxygen consumption is lower in SW than in FW, suggesting that a decreased standard metabolic rate may have contributed to the higher growth rates observed for SW in comparison with FW. Our observations suggest that appetite and feeding activity were greater in SW compared to FW. We also noticed that the intense feeding activity in SW promoted cannibalism, a well-known phenomenon in eel culture (Degani \& Levanon 1983). In teleosts, hypo-osmoregulation has been shown to enhance secretion of $\mathrm{GH}$, which promotes growth, appetite and aggressive behavior (Le Bail \& Boeuf 1997, Jönsson et al. 1998, Boeuf \& Payan 2001). There- 
fore, we suggest that the stimulatory effects of salinity on glass eel growth may result from various effects on metabolism, appetite, feeding and aggressive behaviors, some of them being possibly mediated by increased GH secretion.

Habitat productivity, higher in SW than in FW at high latitudes, was suggested to induce higher growth rates of marine and estuarine eels compared to river eels in Anguilla rostrata (Jessop et al. 2004). Our results indicated that water salinity may also directly promote this phenomenon, irrespective of food availability. Furthermore, our data suggested that intraspecific predation (cannibalism) may be higher in SW than in FW. This may eliminate slow growers and contribute to the apparent fast growth rates of estuarine and marine eel populations.

\section{Link between salinity preference and growth}

In the present study, growth was significantly affected by the 'Contingent' variable, as defined by the behavioral sorting. This indicates that glass eel growth may be linked to salinity preference. Indeed, FWC eels grew least, whatever the rearing salinity condition during the growth experiment. In contrast, SWC eels had significantly higher growth rates in SW than FWC and PCC eels. If we consider that, as discussed above, the SWC and FWC glass eels are representative of marineand estuarine- versus river-colonizers, respectively, our results are in agreement with growth patterns observed in wild populations where estuarine and marine eels grow faster than river eels. Some individuals, called 'nomads', may migrate between marine, estuarine and FW habitats on both seasonal and annual time scales (Arai et al. 2003, Feunteun et al. 2003, Daverat et al. 2004). Growth of PCC eels was not significantly different to that of SWC eels in FW, and to that of FWC eels in SW. Such a growth pattern suggests an intermediary status between SWC and FWC eels, which could lead to a nomad life style.

In all likelihood, the link between glass eel salinity preference and growth rates is related not only to endocrine controls as discussed above, but also to genetic factors. Indeed, on the one hand, salinity tolerance in the guppy Poecilia reticulata (survival after transfer to $35 \%$ SW) is positively correlated to allozyme heterozygosity (Shikano et al. 2000), whereas on the other hand, data from eel farms show the occurrence of strong interindividual growth variations (Elie 1979, Usui 1991). Recent data on Anguilla anguilla revealed that heterozygous individuals for allozyme loci have a significantly higher growth in comparison with more homozygous individuals (Pujolar et al. 2005). These results suggest that, in SWC glass eels, high allozyme heterozygosity could have promoted the preference for high salinity and high growth rates.

In conclusion, our results show that glass eel salinity preference was linked to their locomotor activity and growth performance. This provides a comprehensive ecological mechanism for the control of both habitat distribution and growth patterns observed in wild populations. Furthermore, it suggests that glass eel salinity preference may represent a behavioral trait of major importance for the control of the eel life history plasticity in continental habitats. Studies on the genetic and endocrine control of glass eel migration would allow further investigation of the regulatory mechanisms of eel continental dispersal.

Acknowledgements. We are indebted to D. Mercier, L. Jacobs, M. Pelard and T. Rouault (Cemagref's biological station of Saint Seurin sur Isle) for their invaluable technical support. We thank Dr. F. A. Weltzien (University of Oslo, Norway) for critical comments on the manuscript and for English editing. We also thank P. Camoin (Cemagref) for drawing Fig. 1. This study was partly supported by research grants from GRISAM and Région Aquitaine.

\section{LITERATURE CITED}

Appelbaum S, Chernitsky A, Birkan V (1998) Growth observations on European (Anguilla anguilla L.) and American (Anguilla rostrata Le Sueur) glass eels. Bull Fr Pêche Piscic 349:187-193

Arai T, Kotake A, Ohji M, Miller MJ, Tsukamoto K, Miyazaki N (2003) Occurrence of sea eels of Anguilla japonica along the Sanriku Coast of Japan. Ichthyol Res 50:78-81

Arai T, Kotake A, Lokman PM, Miller JM, Tsukamoto K (2004) Evidence of different habitat use by New Zealand freshwater eels Anguilla australis and A. dieffenbachii, as revealed by otolith microchemistry. Mar Ecol Prog Ser 266:213-225

Baggerman B (1960) Salinity preference, thyroid activity and the seaward migration of four species of Pacific salmon (Oncorhynchus). J Fish Res Board Can 17:295-322

Baggerman B (1962) Some endocrine aspects of fish migration. Gen Comp Endocrinol Suppl 1:188-205

Bertin L (1951) Les anguilles. Payot, Paris

Boeuf G, Payan P (2001) How should salinity influence fish growth? Comp Biochem Physiol C 130:411-423

Cantrelle I (1981) Etude de la migration et de la pêche des civelles (Anguilla anguilla L. 1758) dans l'estuaire de la Gironde. PhD thesis, University of Paris VI

Cardona L (2000) Effects of salinity on the habitat selection and growth performance of Mediterranean flathead grey mullet Mugil cephalus (Osteichthyes, Mugilidae). Estuar Coast Shelf Sci 50:727-737

Castonguay M, Dutil JD, Audet C, Miller R (1990) Locomotor activity and concentration of thyroid hormones in migratory and sedentary juvenile American eels. Trans Am Fish Soc 119:946-956

Davenport J, Sayer MD (1993) Physiological determinants of distribution in fish. J Fish Biol Suppl A 43:121-145

Daverat F, Elie P, Lahaye M (2004) Première caractérisation des histoires de vie des anguilles (Anguilla anguilla) occu- 
pant la zone aval du bassin versant Gironde-GaronneDordogne: apport d'une méthode de microchimie. Cybium Suppl 28:83-90

Deelder CL (1958) On the behaviour of elvers (Anguilla vulgaris Turt.) migrating from the sea into freshwater. J Cons Perm Int Explor Mer 24:135-146

Degani G, Levanon D (1983) The influence of low density on food adaptation, cannibalism and growth of eels (Anguilla anguilla (L.)). Bamidgeh 35:53-60

De Silva SS, Gunasekera RM, Ingram BA, Dobson JL (2001) Weaning of Australian shortfin glass eels (Anguilla australis): a comparison on the effectiveness of four types of fish roe. Aquaculture 195:133-148

Edeline E, Dufour S, Briand C, Fatin D, Elie P (2004) Thyroid status is related to migratory behavior in Anguilla anguilla glass eels. Mar Ecol Prog Ser 282:261-270

Edeline E, Bardonnet A, Bolliet V, Dufour S, Elie P (2005) Endocrine control of Anguilla anguilla glass eel dispersal: effect of thyroid hormones on locomotor activity and rheotactic behavior. Horm Behav 48:53-63

Elie P (1979) Contribution à l'étude des montées de civelles d'Anguilla anguilla Linné (Poisson, Téléostéen, Anguilliforme), dans l'estuaire de la Loire: pêche, écologie, écophysiologie et élevage. PhD thesis, University of Rennes I

Elie P, Daguzan J (1976) Alimentation et croissance des civelles d'Anguilla anguilla L. (Poisson Téléostéen Anguilliforme) élevées expérimentalement, à diverses températures, au laboratoire. Ann Nutr Alim 30:95-114

Elie P, Lecomte-Finiger R, Cantrelle I, Charlon N (1982) Définition des limites des différents stades pigmentaires durant la phase civelle d'Anguilla anguilla L. (Poisson Téléostéen Anguilliforme). Vie Milieu 32:149-157

Fernandez-Delgado C, Hernando JA, Herrera M, Bellido M (1989) Age and growth of yellow eels, Anguilla anguilla, in the estuary of the Guadalquivir river (south-west Spain). J Fish Biol 34:561-570

Feunteun E, Laffaille P, Robinet T, Briand C, Baisez A, Olivier JM, Acou A (2003) A review of upstream migration and movements in inland waters by anguillid eels. Towards a general theory. In: Aida K, Tsukamoto K, Yamauchi K (eds) Eel biology. Springer-Verlag, Tokyo, p 191-213

Fontaine M, Raffy A (1932) Recherches physiologiques et biologiques sur les civelles. Bull Inst Océangr 603:1-18

Gascuel D (1986) Flow carried and active swimming migration of the glass eel (Anguilla anguilla) in the tidal area of a small estuary on the French Atlantic coast. Helgol Meeresunters 40:321-326

Holmgren K, Mosegaard H (1996) Implications of individual growth status on the future sex of the European eel. J Fish Biol 49:910-925

Iwata M (1995) Downstream migratory behavior of salmonids and its relationship with cortisol and thyroid hormones: a review. Aquaculture 135:131-139

Jessop BM, Shiao JC, Lizuka Y, Tzeng CS (2004) Variation in the annual growth, by sex and migration history, of silver American eels Anguilla rostrata. Mar Ecol Prog Ser 272: 231-244

Johansson V, Winberg S, Jönsson E, Hall D, Björnsson BT (2004) Peripherally administered growth hormone increases brain dopaminergic activity and swimming in rainbow trout. Horm Behav 46:436-443

Jönsson E, Johnsson JI, Björnsson BT (1998) Growth hormone increases aggressive behavior in juvenile rainbow trout. Horm Behav 33:9-15

Jung S, Houde ED (2003) Spatial and temporal variabilities of pelagic fish community structure and distribution in Chesapeake Bay, USA. Estuar Coast Shelf Sci 58:335-351
Krueger WH, Oliveira K (1999) Evidence for environmental sex determination in the American eel, Anguilla rostrata. Environ Biol Fish 55:381-389

Le Bail PY, Boeuf G (1997) What hormones may regulate food intake in fish? Aquat Living Resour 10:371-379

McCleave JD, Kleckner RC (1982) Selective tidal stream transport in the estuarine migration of glass eels of the American eel (Anguilla rostrata). J Cons Int Explor Mer 40:262-271

McCleave JD, Wippelhauser GS (1987) Behavioural aspects of selective tidal stream transport in juvenile American eels. Am Fish Soc Symp 1:138-150

McCormick SD (2001) Endocrine control of osmoregulation in teleost fish. Am Zool 41:781-794

Mounaix B, Fontenelle G (1994) Anguilles estuariennes et fluviales: apports de l'otolithométrie. Bull Fr Pêche Piscic 335:64-68

Oliveira K, McCleave JD, Wippelhauser GS (2001) Regional variation and the effect of lake: river area on sex distribution of American eels. J Fish Biol 58:943-952

Overli O, Kotzian S, Winberg S (2002) Effects of cortisol on aggression and locomotor activity in rainbow trout. Horm Behav 42:53-61

Petit G, Vilter V (1944) Stabulation des civelles à l'embouchure d'un fleuve du golfe de Marseille. CR Séances Soc Biol Paris 138:632-634

Pujolar JM, Maes GE, Vancoillie C, Volckaert FA (2005) Growth rate correlates to individual heterozygosity in the European eel, Anguilla anguilla L. Evolution 59:189-199

Schmidt J (1909) Remarks on the metamorphosis and distribution of the larvae of the eel. Medd Komm Havunders Ser Fiskeri 3:1-17

Shikano T, Chiyokubo T, Nakadate M, Fujio Y (2000) The relationship between allozyme heterozygosity and salinity tolerance in wild and domestic populations of the guppy (Poecilia reticulata). Aquaculture 184:233-245

Sola C (1995) Chemoattraction of upstream migrating glass eels Anguilla anguilla to earthy and green odorants. Environ Biol Fish 43:179-185

Sorensen PW (1986) Origins of the freshwater attractant(s) of migrating elvers of the American eel, Anguilla rostrata. Environ Biol Fish 17:185-200

Sorensen PW, Bianchini ML (1986) Environmental correlates of the freshwater migration of elvers of the American eel in a Rhode Island brook. Trans Am Fish Soc 115:258-268

Stone R (2003) Freshwater eels are sleep-sliding away. Science 302:221-222

Tesch FW (2003) The eel. Blackwell, Oxford

Tosi L, Sola C (1993) Role of geosmin, a typical inland water odour, in guiding glass eel Anguilla anguilla (L.) migration. Ethology 95:177-195

Tosi L, Sala L, Sola C, Spampanato A, Tongiorgi P (1988) Experimental analysis of the thermal and salinity preferences of glass eels, Anguilla anguilla (L.), before and during the upstream migration. J Fish Biol 33:721-733

Tosi L, Sola C, Spampanato A, Tongiorgi P (1989) The behaviour of glass eel of Anguilla anguilla toward salinity: discrimination and preferences. Riv Ital Acquacolt 24: 219-223

Tosi L, Spampanato A, Sola C, Tongiorgi P (1990) Relation of water odour, salinity and temperature to ascent of glass eels, Anguilla anguilla (L.): a laboratory study. J Fish Biol 36:327-340

Tsukamoto K, Arai T (2001) Facultative catadromy of the eel Anguilla japonica between freshwater and seawater habitats. Mar Ecol Prog Ser 220:265-276

Tzeng WN, Severin KP, Wickström H (1997) Use of otolith 
microchemistry to investigate the environmental history of European eel Anguilla anguilla. Mar Ecol Prog Ser 149: $73-81$

Tzeng WN, Shiao JC, Lizuka Y (2002) Use of otolith Sr:Ca ratios to study the riverine migratory behaviors of Japanese eel Anguilla japonica. Mar Ecol Prog Ser 245:213-221

Tzeng WN, Lizuka Y, Shiao JC, Yamada Y, Oka HP (2003) Identification and growth rates comparison of divergent migratory contingents of Japanese eel (Anguilla japonica). Aquaculture 216:77-86

Usui A (1991) Eel culture. Blackwell, Cambridge, MA

Vøllestad LA (1992) Geographic variation in age and length at

Editorial responsibility: Howard I. Browman (Associate

Editor-in-Chief), Storebø, Norway metamorphosis of maturing European eel: environmental effects and phenotypic plasticity. J Anim Ecol 61:41-48

Wickins JF (1987) Effects of size, culling and social history on growth of cultured elvers, Anguilla anguilla (L.). J Fish Biol 31:71-82

Wilson JM, Antunes JC, Buça PD, Coimbra J (2004) Osmoregulatory plasticity of the glass eel of Anguilla anguilla: freshwater entry and changes in branchial ion-transport protein expression. Can J Fish Aquat Sci 61:432-442

Wippelhauser GS, McCleave JD (1988) Rhythmic activity of migrating juvenile American eels Anguilla rostrata. J Mar Biol Assoc UK 68:81-91

Submitted: March 24, 2005; Accepted: June 28, 2005

Proofs received from author(s): November 20, 2005 